\title{
撮像管に関する最近の研究と開発の動向
}

\author{
正会員二 宮 輝 雄†
}

撮像管に関する最近の研究, 開発, 製品化の動向を, できるだけ広くとらえて要約したあのである.

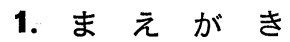

昨年の全国大会シンポジウムで, 「……撮像管の全盛 時代はまさにてれから始まろうとしている……現状から 類推すると（我が国の撮像管）年間生産数が 200 万本を 越えるのむそう遠くないと思われる」〉述べたが， 1 年経過して，今のとてろ，ての前言は訂正しなくてょさ そうである．昭和 55 年度の生産数は前年の 1.4 倍位に 増加し，140万本位（日本電子機械工業会の統計に含ま れない分む適当に加算した值）になっていると推定され る.

ここ 2,3 年の急上昇は家庭用単管式カラーカメラの撮 像管によるとてろが大きく， その他の撮像管む増加して きている，てれにとむなって，性能向上に対する注力む 活発であり, 多くの新しい改良開発やユニークな基礎研 究がいろいろ行わ机ている. これらの一部については, すでに，本誌にも解説記事がいくつか出ているので23)， 本文では同じような解説を繰り返すととを避け, 最近の 研究, 開発, 製品化の動向をできるだけ広くとらえて要 約するとととした.

\section{2. 光導電ターゲット}

既存の各種光導電ターゲットの改良, あるいは目的に 応じた変更がいろいろ行われた，放送用などの高画質化 を目指した管の改善は精力的に進められており，サチコ ンではターゲットの出力浮遊容量を減らして S N比を改 善するため, 出力取出しをピンリード形にした管が, 1 インチ管, $2 / 3$ インチ管で製品化されだ).

プランビコンむセラミックシグナルリングを採用して 改良はしているが，さらにいっそう改善した $2 / 3$ インチ 管の製品化が進められており ${ }^{5)}, 1$ インチ管であ開発が 予定されている.

$\dagger$ 東京芝浦電気株式会社 総合研究所

"Recent Reseach and Developments on Camera Tubes" by Teruo

Ninomiya (Toshiba Research and Development Center, Kawasaki)

$608(2)$
また， 30 ミリ管を 1 インチ管の光学サイズで縮小走査 し，中央部分のみを使うことで，レジストレーションや 解像度の一様性を高め, しかもネ電極を必要最小の大 きさにして，ピンリード形にした管の開発が，サチコ ン,プランビコン, レディコンなどについて外国数社で 進められている.

これら一連のターゲット出力容量を減らす動きが活発 になってきた裏には，ヘッドアンブの初段に使用する FET の低雑音化があり，乙れらを推進した蔭の力に負 うところが大きい(67). これによって，乙て数年の間に アンプノイズが $10 \mathrm{~dB}$ 近く改善されてきたことは注目に 価しよう.

この他，3管式ではカメラのいっそうの小形軽量化を ねらって，放送用レベルの $1 / 2$ インチサチコンが RCA で開発，製品化された ${ }^{90)} .400 \mathrm{TV}$ 本での振幅変調度は 40\%と高い. プランビコンについてす $1 / 2$ インチ管の開 発が海外で進んでいる.

新しい光導電材料としては，アモルファスシリコンの ターゲットが注目されるが，まだ研究試作の段階にあ $3^{8999}$.

次に，それぞれのターゲットについて，乙て数年の研 究や開発の状況をごく簡単に述べる.

\section{(1) $\mathrm{Sb}_{2} \mathrm{~S}_{3}$ ビジコン}

テレシネの画質改善のため, ビジコンのフレアについ て検討された．フレアはネサ厚およびそれに接する薄い 高真空蒸着層の膜厚と関係が深いことをつきとめ, フレ ア防止チップを付加することで 4 割位これを軽減させ た.これによって, 視覚的な解像感と雑音が改善され $た^{10)}$.

（2）プランビコン, Pbo ビジコン

プランビコンはターゲットの膜厚が比較的厚く， 1 1 ンチ管で 15 20 $\mu \mathrm{m}$ あり，乙れが解像力を制限してい たが，乙れを 11〜15 $\mu \mathrm{m}$ と薄くして解像力を上げ（垂 直縞チャート $5 \mathrm{MHz}$ に扔ける中心部の振幅変調度, 緑 用で $40 \%$ から $60 \%$ に)，膜厚を薄くしたてとによる残 
像の増加は, ビーム温度の低いダイオード ガンを開発して防いだ. 1インチ管の他, $2 / 3$ インチ管む製品化されている11).

$\mathrm{PbO}$ ビジコンについては, $\mathrm{PbO}$ の蒸着 条件が多結晶膜の結晶配向性に影響を与え ることを指摘し，膜厚方向に長辺をむつ結 晶が多く並ぶような構造とすることで解像 度を上げた研究がある12)13)。

\section{(3) カルニコン}

電子ビームの走査を休止して光パルスを照射し, 信号 電荷がターゲットにどの位保持するか調べられた ${ }^{14)}$. ま た残像特性を改良するため, $\mathrm{CdSeO}_{3}$ と $\mathrm{As}_{2} \mathrm{Se}_{3}$ の間に $\mathrm{Sb}_{2} \mathrm{~S}_{3}$ と $\mathrm{As}_{2} \mathrm{Se}_{3}$ を同時蒸着した層を入れ，暗電流を適 度に増すことにより，立上り残像を改善した管や15)， $\mathrm{As}_{2} \mathrm{Se}_{3}$ 層を米粒状あるいは柱状が並立する構造とする ことで, 残像, 立上り特性を改良した報告む出されてい $ろ^{16)}$.

この他, CdSe 膜の一部を $\mathrm{CdTe}$ 化して $900 \mathrm{~nm}$ 近く まで近赤外感度をむたせた $\mathrm{CdSe}(\mathrm{Te})-\mathrm{As}_{2} \mathrm{Se}_{3}$ 構造の夕 一ゲットがつくられた17). 暗電流は 1 インチ管で $2 \mathrm{nA}$ 位， $\gamma$ は白色光，赤色光でほぼ 1 に近く，緑と青色光で 約 0.9 である. 量子効率は可視域で $0.8 \sim 0.9$, 伸長し た近赤外域で $0.9 \sim 0.95$ と高く, $2,856 \mathrm{~K}$ の白色光感度 は通常のカルニコンの 2 倍位ある.

\section{(4) サチコン}

開発初期の膜は As, Te の分布を再検討することで改 良され，焼付がいっそう少なくなった。サチコン膜の詳 細な動作機構は非晶質材料のため, 解明しつくされてい ないが，その電子構造について適当なモデルを仮定して 解析を行い，サチコン特性のかなりの部分が，バンド的 な振舞をするキャリヤーによって支配されていると考え て説明できることがわかった ${ }^{18)}$. また, 単管式カラーカ メラに用いた場合の $\mathrm{Sb}_{2} \mathrm{~S}_{3}$ 膜との比較報告むある ${ }^{19)}$.

なお最近，容量性残像をいっそう少なくするため，膜 厚を $4 \mu \mathrm{m}$ から $6 \mu \mathrm{m}$ 位に増した $2 / 3$ インチ管, 1 イン チ管む製品化されており，乙れらの管ではターゲット電 王が, 従来の $50 \mathrm{~V}$ から $65 \mathrm{~V}$ に上げられている4).

\section{(5) ニュービコン}

初期の膜は暗電流が, $2 / 3$ インチ管, $25^{\circ} \mathrm{C}$ で $5 \mathrm{nA}$ と 多かったが, $\mathrm{ZnSe}$ 層に続く狭い禁止帯の $\mathrm{Zn}_{x} \mathrm{Cd}_{1-x} \mathrm{Te}$ (In) 層が, 暗電流発生源のひとつであるととをつきと め, その厚さや成分比を検討するてとで，1.5nA 減 らした ${ }^{20)}$. また電子ビーム走査側につける無定形阻止層 む暗電流を抑え, 残像の低減に効果のあることが確かめ られた 211 .

近赤外増感形も製品化されているが，てれはターゲッ
ト構造は変えず, $\mathrm{CdTe}$ 量を約 30\% 増すととすに, In が中心となる増感センターを増すととで, 可視域から約 $940 \mathrm{~nm}$ の近赤外まで感度をむたせている22). この他, 光入射側にある $\mathrm{ZnSe}$ 層を $\mathrm{ZnS}$ と $\mathrm{CdS}$ の固溶体に変 更し，青感度を $25 \%$ 高めた管む製品化されていたが23), 最近のカタログからは除かれている. また, 単管式カラ 一カメラ用に開発されたニューコスビコンの光導電膜 は, カラー用として過剰な長波長感度を削減し, 低暗電 流化してある24).

\section{（6） シリコンビジコン}

シリコンビジコンは, フィールドメッシュから発生する 軟 $\mathrm{X}$ 線のために暗電流増加によるラスター焼付きを生 じ，短寿命であったが，メサ形ターゲットの走査側に蒸 着する抵抗膜に $\mathrm{PbO}$ を選ぶことでメッシュ電圧 500 $\mathrm{V}, 10,000$ 時間における暗電流増加 $2 \mathrm{nA}$ 以下と大幅に 改善された ${ }^{25)}$.

また， $\mathrm{PbO}$ 抵抗膜をつけた条件で，プレーナ形ター ゲットとメサ形ターゲットを比較すると, 後者は暗電流 の増加が少なく, ビームランディング特性む優れ, 解像 度が高く, 残像む少ない26)27).

（7） アモルファスシリコンターゲット

$\mathrm{SiH}_{4}$ をグロー放電で分解してつくる方法 ${ }^{8}$ と $\mathrm{SiH}_{4}$ の 水素雾囲気中での反応性スパッタリングでつくる方法 ${ }^{92}$ とが研究されており，共に阻止形ターゲットになるよう

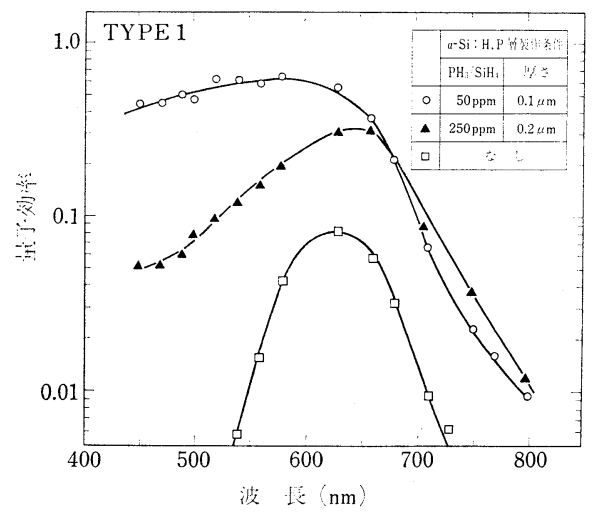

図 2 分光感度特性（図 1, タイプIのターゲット） 


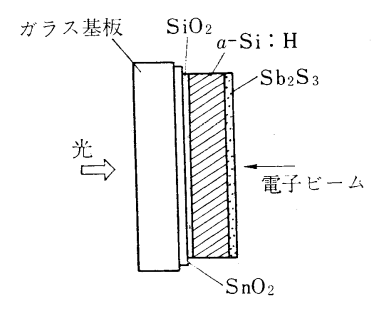

図３スパッタリング法でつくったアモルフ アスシリコンターゲットの構造

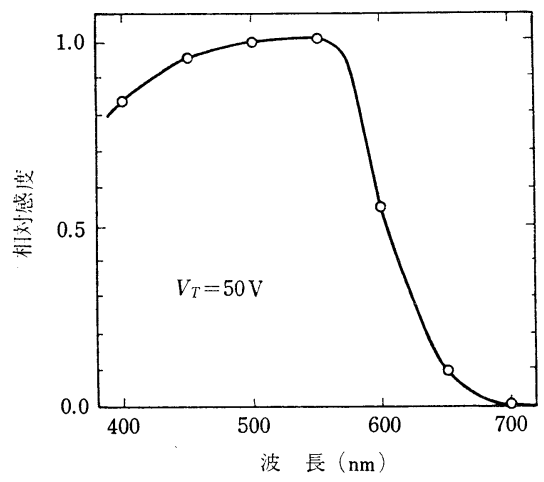

図 4 入射光子数で規格化した分光感度（図 3 のターゲット）

工夫している，前者で試作されたターゲットの構造, 分 光感度をそれぞれ 図 1，図2亿示す.

光入射側の $n$ 形層には燐をドープしたタイプ I と, $\mathrm{Si}$ の一部を $\mathrm{N}$ (窒素) で置換したタイプIIが試みられてい るが, タイプIIの分光感度は図 2 のタプ I の中で青感 度のむっとも高い曲線に近い. 3 フィールド後の残像值 は, $2 / 3$ インチ管について信号電流 $0.2 \mu \mathrm{A}$, バイアスラ イト $5 \mathrm{nA}$ で約 $5 \%$ が得られている.

後者で試作されたターゲットの構造，分光感度をそれ ぞれ図3，図4亿示す。残像は，バイアスライトなしで 他は上之同じ条件で約 $9 \%$ あった。

\section{3. 電子ビーム}

\section{1 電子ビーム系全般に関係するもの}

電子ビーム径を決めるざまざまな要因を整理し， 数表を多くとり入れて, ビーム径の限界を論じた報 告28), ビジコン電極系で直接ビームスポットの電流 密度分布を測定し，さらにクロスオーバー付近の状 態を調べた研究29930)，NEA 冷陰極を用いた場合に 特有の撮像管電子レンズ系について解析し，ボンデ イングワイヤの影響などむ含めて検討したもの ${ }^{311}$, あるいは電極系製作技術の一端を紹介したもの ${ }^{322}$ な どがある.

\section{2 電子銃}

$610(4)$
第 1 グリッドをカソードに対して正電位で動作させる 層流形あるいは，準層流形電子銃はダイオードガンとも 呼ばれ，最近とくに注目されてきた。この電子銃では電 荷密度の上がるクロスオーバー点をもたないので，カソ 一ドから出た電子は途中で相互に干渉するととが比較的 少なく,ターゲットへ到達するときの速度分布む余り広 がらない，そのため容量性残像の低減に効果があり，解 像度を上げ，しかむ残像を低くおさえるのに有利であ る1133). こ机牸は本誌であ解説されているので2), ここでは省略し，カソードに重点をおくこととするが， 他に電子銃関係では，ACT ガン付プランビコンの解像 度が改善され，1インチ管と 30 ミリ管で製品化され $た^{34)}$.

\section{（1）熱陰極}

酸化物陰極について，その寿命は酸化物層とその直下 にある基体合金中の還元剤との相互反応によってきま り，基体金属に $\mathrm{Ni}-4 \% \mathrm{~W}-\mathrm{Mg}$ を用いたものよりむ $\mathrm{Ni}-\mathrm{Ba}-\mathrm{Mg}$ を用いた方が長寿命であるとと，速動形力 ソードについてむ, Ni-Ba-Mg 形は 30,000 時間近く経 過して，90〜98\%のエミッションを保持し，優れている ことなどが確かめられた ${ }^{35}$.

含浸形カソードは高電流密度が得られ，寸法精度を高 くつくれるなどの特長のために，高精細度用などにむ使 用されているが33)，含浸材料を焼成するとき，炭酸ガス を含む雾团気で行うと，完全溶融し，水分に対してあ安 定で良好な電子放射特性を示す ${ }^{36)}$.

含浸形カソードでは，良質のカソード素材を製作する ことと同時に，適切な前処理技術および排気技術が重要 であり，乙れらのプロセスや各種のガスによる被毒特性 について調べられた．被毒を受忊易いガスは $\mathrm{H}_{2} \mathrm{O}, \mathrm{O}_{2}$, $\mathrm{Air}, \mathrm{SO}_{2}$ などであり，比較的被毒されにくいガスは $\mathrm{CO}$, $\mathrm{CH}_{4}, \mathrm{~N}_{2}, \mathrm{Ar}, \mathrm{H}_{2}$ である ${ }^{37)}$.

(2) NEA 冷陰極

撮像管に適用することをひとつの目的として研究が続 けられ，最近 GaP-GaAlP 異種接合形扔よび $\mathrm{GaP}$ 形に ついて，かなり進んだ結果が得られている. 前者の構造

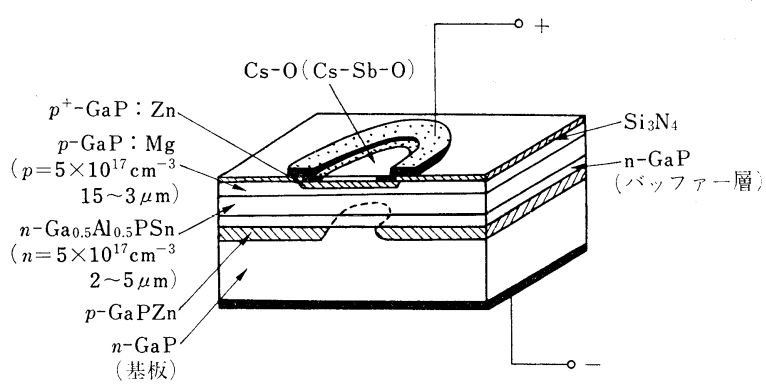

図 $5 \mathrm{GaP}-\mathrm{GaAlP}$ 異種接合冷陰極の構造 


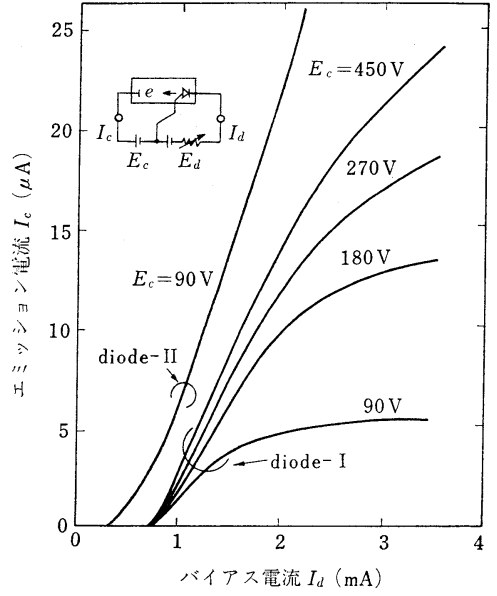

図 $6 \mathrm{GaP}-\mathrm{GaAlP}$ 冷陰極のエミッション特性例 $\left(E_{c}\right.$ はコレクタ電位 $)$

を図 5 亿示す.ての構造の冷陰極から得られたエミッシ ョン電流特性を図 6 亿示す. 図では $2 つ の$ 代表例が示さ れているが, diode-II ではバイアス電流 $2 \mathrm{~mA}$ で $22 \mu \mathrm{A}$ という，高いエミッション効率が得られている38).

また，乙の異種接合形を $\mathrm{Cs}, \mathrm{Sb}, \mathrm{O}_{2}$ あるいは $\mathrm{Cs}, \mathrm{Ag}$ ， $\mathrm{O}_{2}$ で活性化するという新しい手段によって，0.1A 程 度のエミッションを 6,000 時間以上にわたって保持する ことができた ${ }^{399}$ 。これらの実験は $10^{-10} \sim 10^{-11} \mathrm{mmHg}$ 程度の超高真空に排気した管で行われている.

$\mathrm{GaP}$ 形では, これを用いて層流形電子銃を作り, 非 晶質セレン执よびサチコンのターゲットで撮像管として の特性が調べられた．電子放射面は直径 $50 \mu \mathrm{m}$ の円形 で，ターゲット上でビーム温度 $600 \mathrm{~K}$, 限界解像度 800 TV 本が得られている。 この実験は $10^{-7} \mathrm{~Pa}(\fallingdotseq 0.75 \times$ $10^{-9} \mathrm{mmHg}$ ) 以下の高真空で行われた ${ }^{40)}$.

\section{3 集束偏向系}

（1）磁界集束磁界偏向形（MM 形）

3 管式カラーカメラやモノクロ用では，な拉主流とし て多く用いられており, 前者では特に小形化のため, 全 長を $85 \mathrm{~mm}$ 汇短縮した $2 / 3$ インチ管あある ${ }^{41}$. また， 高解像度化のため, 2 ループ集束方式や 2 ループでしか む $\mathrm{G}_{3}$ 電極を 2 分割し，バイポテンシャルレンズを形成 した複合集束方式が提案され，1インチビジコンで限界 解像度 $1,600 \mathrm{TV}$ 本を得ている ${ }^{42)} 43$.

変ったところでは，宇宙用などに集束コイルアセンブ リ一の軽量化之消費電力の削減を称らって， SmCoのよ うな永久磁石を使用する研究が進んでいる ${ }^{44)}$.

(2) 電界集束磁界偏向形 (SM 形)

単管式カラーカメラ用は, 軽量化之低消費電力化のた め，ほとんどが SM 形になっているが，良質の画を得る
ために高い解像力とその周辺までの一様性が特に厳しく 要求される. そこで, 解像力を高めるためメッシュ電圧 を $1,500 \mathrm{~V}$ 前後に上げて使っているが, 周辺解像度の低 下を防ぐために，電子ビーム発散角を小さくする補助電 極を設け, 電界集束部を 5 極構造とした例や45)，偏向収 差を解析して, 静電レンズ長を従来管より $10 \%$ 増し, 偏向磁界の中心之静電レンズの中心との距離を従来管の 3 倍強に拡大した例などがある46).

（3）磁界集束電界偏向形 (MS 形)

理想的な一様電磁界中でこの集束偏向が行われたとす ると，集束面は平面となり，収差を生じない，また，管 軸方向に放射された電子ビームは集束面でも垂直にラン ディングするなどの本質的には優れた方式である．さら に小形軽量, 低消費電力の特長むあって, 画質のいっそ うの高度化とともに注目されてきている.

GE で 15 年位前に研究され，実用化されているが47)， 我が国でもとれに対する軌道解析が行われ, 実際の撮像 管のように電磁界が一様でない場合を，定性的な分析を 含めて解析し, ランディングエラーを補正し, 縮小投影 が可能なととを見出した ${ }^{48}$.

現在, 単管式カラーカメラに一部で実用化されてい る ${ }^{49)}$.また, ピアス形の層流形電子銃との組合せ実験む 行われている50).

(4) 電界集束電界偏向形 (SS 形)

直交させた 2 組の平板形電極系によって，それぞれ水 平之垂直方向の集束を順次行い，同時に各方向の偏向 あ行わせる方式が，H. G. Lubszynski らによって発表 されていたが511，乙れを見直す実験が日本で行われ，か なり良い結果が得られている.

1 対の平行平板電極をメッシュ電極で置き換え, 全長 を短縮した試作実験や52)，さらにてのメッシュ電極をス リット構造に置き換える実験が行われた ${ }^{533}$. SS 形はコ イルアセンブリーが不要で, ランダムアクセススキャン の可能性むあり, これらの特長は今後, 活かされるかむ 知れない。

また，単管式カラー用でとくに問題となる水平偏向直 線性の垂直方向との相関を MM 形, SM 形, SS 形につ いて調べ, SS 形で電極組立精度を上げた場合が最適之 の報告むある ${ }^{54)}$.

\section{4 ビームランディング}

低速度ビームがターゲットを走査していくとき，ター ゲットへの吸収のされ方を微細汇考えると，ビーム断面 の前縁は電位の高い部分に最初に接するので吸収が大き く，後縁では少なくなる，したがって，ビーム断面は円 形でむ，実効的に㗢く部分は，たとえば三日月形などに 変形し，解像力には異方性が生じる. 
この現象は古くから指摘されていたが, 最近, 近似的 な仮定の下に精力的な解析が行われ，ビームの電流密度 分布, ターゲットの蓄積容量, ビーム温度, 信号電流, ビーム電流, ビーム集束角, 走查線数, インターレース 比などと関連して，いろいろ興味ある結果が得られてい

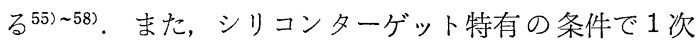
元モデルをたてビームはガウス分布形と仮定した解析む 行われている599.

解像度の測定は古くて新しい問題であり, 使用するテ ストパターンの種類, 管の各種の調整条件, 信号増幅系 の周波数特性, レンズなどの光学系の特性, 画面中の位 置などに関係し，単に $400 \mathrm{TV}$ 本の振幅変調度が何\%と いう数值だけでは判断しにくい問題を含んでいる.

これについて，測定に用いる縞パターンの走查線に対 する角度が 7 種類あるテストチャート（RCA P-300) を作成し, 解像力の異方性を含めて評価する方法が提案 されており，実際の管について興味ある測定結果が得ら れている60).

一般に, 走查方向と直交する垂直縞パターンで測定し た方が, 斜め縞パターンよりむ大きい振幅変調度が得ら れるが, 斜め縞であ, 右下がりと左下がりで異なるとと が多い，一方を最良条件に調整すると，他方がひどく劣 化することもおこるので, 両者が同じ振幅変調度になる ような, バランスのとれた条件を求めて測定すべきであ るとの思想から， RCA P-200 のテストチャートがつく られた ${ }^{611}$.

容量性残像之の関係については，すでに吉永をはじめ 多くの解析があるが, 最近, 実測により求められるビー ムアクセプタンス曲線から残像を計算できるようにな り, 細部の解明がいっそう進んだ5862). また, 回路的に 容量性残像を改善する方法として, 出力信号をカソード にうまくフィードバックして，入射光の有無による(走 査直後の）面電位平衡点の差をなくし, 残像の消滅を図 る試みむ行われているが，まだ実用化には至っていな (163)64).

残像測定については，マイコンを導入して精度の向上 と省力化を図った報告 ${ }^{65)}$ や, 可変波長光パルス光源での 測定報告がある66).

この他, 高速度ビーム走查方式の特長を見直す解析之 実験む行われている67).

\section{4. 色分離フィルター内蔵形撮像管}

20 年以上にわたって, 単管式や 2 管式カラーカメラの 研究開発は続けられてきたが, 本格的な量産が軌道にの り出したのは，乙こ2〜3 年であり，それにとむなって 最近の画質は全般的にかなり良くなってきた. 本誌に色
フィルター技術を含め, 現在使われている各種の単管式 カラーカメラについて, 進歩の苦心の跡が解説されたば かりであるので3)，ここでは重複する記述を避け，でく 最近の動きに重点をおくこととする.

3 年位前までは 1 インチ管が多かったが，現在はほと んどが $2 / 3$ インチ管になっている. 光導電膜には $\mathrm{Sb}_{2} \mathrm{~S}_{3}$ を使用し，有機質の色フィルターを内蔵した管が圧倒的 に多いが，サチコン膜を使用した管むかなり増加して， 月産 5 析の数 (単一搬送波周波数分離方式 - 色搬送波周 波数 $3.6 \mathrm{MHz} \cdot \mathrm{SM}$ 形，その他）になってきいてる.

またニュービコン膜の構造をカラー用に少し変え（前 述), 無機質のダイクロイックフィルターを内蔵した管 あ製品化された ${ }^{68)}$. 単一搬送波周波数分離方式・SM 形 で，色搬送波周波数は 1 インチ管が $3.8 \mathrm{MHz} ， 2 / 3$ イン チ管が $3.58 \mathrm{MHz}$ である.

1/2 インチ管はまだ製品化されていないが，VTR一 体形カメラ用としての提案がなされており ${ }^{699}$, 乙れ関 連して, 単一搬送波周波数分離方式で, 色搬送波周波数 が $2 / 3$ インチ管と同等以上の $1 / 2$ インチ管む試作されて いるとのととである.

3電極形では，赤緑青のストライプフィルターに合わ せてネサ電極を分割し，同色どうしを接続するために立 体配線を必要とするなど，より高度の製作技術が要る か $^{70)}$, 業務用としての限界解像度 $450 \mathrm{TV}$ 本の 3 電極严 チコン ${ }^{71)}$ の他に, 家庭用として面板付近の径だけを 28.7 $\mathrm{mm}$ に広げた $2 / 3$ インチ $\mathrm{SM}$ 形 3 電極ビジコン (走査 面積 $7.2 \times 9.6 \mathrm{~mm}^{2}$, 全長 $114 \mathrm{~mm}$ max.) む製品化さ れ, 限界解像度は $270 \mathrm{TV}$ 本に改良されている.

3 電極形では出力浮遊容量が增すので, $\mathrm{SN}$ 比の改善 に工夫がこらされているが,メッシュ電極からも信号を 取り出し, これを電極からの信号に加えるととで SN 比 が若干改善されるとの研究むある72).

位相分離形では $\mathrm{Sb}_{2} \mathrm{~S}_{3}$ 膜の他に ${ }^{49}$ ，2/3 インチサチコ ンの MS 形で，色搬送波周波数 $4.5 \mathrm{MHz}$ ，水平解像度 $300 \mathrm{TV}$ 本のカメラが商品化されているが, 乙の他同系 統の管で, 色搬送波周波数 $6 \mathrm{MHz}$, 水平解像度 $410 \mathrm{TV}$ 本のカメラむ発表されている73). この管では色フィルタ 一のピッチは赤緑青 1 組で $27 \mu \mathrm{m}, 1$ 色あたり $9 \mu \mathrm{m}$ と 細かくなっている.

\section{5. 特殊用途の撮像管}

\section{1 高精細度用}

NHK で進められている走查線数 1,000 本以上の高精 細度テレビジョンの研究の一環として，2インチリター ンビームサチコンや1インチ高品位テレビ用サチコンが 開発された. 数十 $\mathrm{MHz}$ 以上の帯域になると, 直接ター 
ゲット電極から信号を取り出すよりむ，イメージオルシ コンのように信号成分を含むリターンビームを管内で 2 次電子増倍し, 大きい出力として取り出す方が $\mathrm{SN}$ 比が 改善される.

そこでリターンビーム形の 2 インチサチコンが開発さ れたが ${ }^{74)}$ ，乙れを 2,125 本の走査線で動作させ, 高解像 度の白黒 CRT に表示すると，見なれたテレビの画とは かなり異質の，きめの細かい，きれいな写真を見ている ような画面が得られる. しかし，乙の管はターゲットの 蓄積容量が $7,000 \mathrm{pF}$ 位あり, そのため残像が多く, 動 きの多い普通の被写体には使用できない.

そこで， 1, 125 本の高精細度テレビ用に充分な解像力 をむち, しかも残像の少ない撮像管が開発された ${ }^{33)}$. 乙 れは $1,600 \mathrm{TV}$ 本以上の解像度をむつ 1 インチサチコン で，含浸形カソードを使用し， $\mathrm{G}_{1}$ の径が $15 \mu \mathrm{m}$ 以下の 特殊なダイオードガンを用いて，ビーム温度を $1,700 \mathrm{~K}$ に下げている. そのため, バイアスライトなしの条件で む, 3 フィールド後の残像値は $1 \%$ (信号電流 $0.5 \mu \mathrm{A}$ ) 以下になっている.

中央部における振幅変調度は右下りの斜め縞チャート で， $1,000 \mathrm{TV}$ 本において $33 \%$ (レンズの振幅変調度 $72 \%$ を含んだ值で，信号電流 $0.5 \mu \mathrm{A} ， 3$ 倍のビームセ ット) である.

また，高解像度システム用にダイオードガンの 30 ミ リプランビコンもつくられており， $5 \mathrm{MHz}$ における中 央部の振幅変調度は, EIAJ $B_{2}$ チャート (垂直縞) を使 用し， $V_{G 4}=675 \mathrm{~V}, V_{G 3}=300 \mathrm{~V}$, ビーム電流 $0.6 \mu \mathrm{A}$, 信号電流 $0.3 \mu \mathrm{A}$ で, 約 $75 \%$ になっている.

\section{2 超高感度用}

近接集束形 SEC ビジコンについては 10 年位前, プ ロキシコンの商品名で Fernseh と Westinghouse が共 同開発しているが, 技術的問題がいろいろ残され，その 後む解決の努力が続けられていた. 最近の状況ははっき りしていないが, 我が国でマルチアルカリ光電面によっ て, 高感度で寿命の長い近接形を製作する技術が開発さ れるとともに，過大な入射光に対し安定で丈夫な $\mathrm{MgO}$ ターゲットや，さらにこの特長の上にいっそうの画質改 善を行った $\mathrm{MgF}_{2}$ ターゲットの開発，抑制メッシュの 除去による SN 比の改善などの成果が得られた ${ }^{75) 76)}$. 通 常の 10 倍以上の高感度で, かなりの画質が期待できる.

また，乙の近接形光電面の製作技術を用いて，近接集 束形イメージインテンシファイヤー (I.I.) が開発され た ${ }^{7778)}$. この近接 I. I. 形とファイバープレート付サチ コンを結合したカラーカメラの実験む行われ, 標準カメ ラの 15 20 倍の感度が得られている75). この他, 超高 感度監視用として, I. I. と直接結合できるファイバープ
レート付ニュービコンが製品化されている ${ }^{79)}$.

イメージ管のターゲット部に CCD のイメージャンサ 一を組み込み, これに光電面からの光電子をフォーカス させる条件で数 $\mathrm{kV}$ 以上の速度で射突させ，高い利得を 得るようにした超高感度撮像管 SIT/CCD が開発され た. 光電子の加速電圧を $4 \sim 12 \mathrm{kV}$ 位に変化させること で感度を調節でき, SIT (Silicon-Intensifier Target) 管 と同様, 最大 2,000 倍位の電子増倍ができる. しかし, SIT 管と異なり, 残像がなく, ブルーミングむ少ないと のことである. 水平限界解像度 $240 \mathrm{TV}$ 本, 垂直限界解 像度 $480 \mathrm{TV}$ 本である ${ }^{80)}$.

マイクロチャンネルプレートを組み込んだ近接集束形 I. I. を CID (Charge-Injection-Device) イメージセンサ 一とファイバープレートで結合した Intensified CID カ メラも製品化されている. 光電面は可視域 (S-20) 以外 に真空紫外 $\left(\mathrm{CsI} / \mathrm{MgF}_{2}\right)$ から近赤外 (S-1) までいろいろ と選択でき, フェースプレートの最大入力照度は $0.5 \times$ $10^{-4} \mathrm{fc}$ の超高感度である ${ }^{81)}$.

\section{3 不可視光用, その他}

人工衛星からのオーロラ観測を目的亡して, 真空紫外 域にのみ高い感度をむつ撮像蓄積管が開発された. $\mathrm{MgF}_{2}$ の面板と $\mathrm{KBr}$ 光電面を用い, マイクロチャンネルプレ 一ト (MCP) を 2 枚組み込むことで最大 $10^{5}$ 倍位の利得 を得ている. MCP の入力側表面に直接光電面を蒸着し て, イメージ部分を不要とし, 走査側は電界集束電界偏 向形として，小形軽量化を図っている. 全長 $160 \mathrm{~mm}$, 外径は光電面側 $41 \mathrm{~mm}$, 走査側 $25.4 \mathrm{~mm}$ で, 解像度 $200 \mathrm{TV}$ 本が得られている ${ }^{82)}$.

紫外線用としては，との他に電界集束形イメージ管の 試作報告がある．ファイバープレートを入力側に使用で きないので，石英の平板上に光電面を形成し，近接メッ シュで光電子を加速する方法で周辺解像度を上げてい る. 光電面, 螢光面は共に $16 \mathrm{~mm} \phi$ で, $\mathrm{MCP}$ を用い ない時の限界解像度は $4,000 \AA$ の単色光で測って, 中心 $551 \mathrm{p} / \mathrm{mm}$, 周辺 $30 \mathrm{lp} / \mathrm{mm}$ である ${ }^{83)}$.

焦電形赤外線ビジコンについては, DTGS* を焦電材 料亡し，解像力を上げるため，乙れを図７に示すように イオンビームエッチングで細かく分割した構造のターゲ ットが発表され, 図8のような結果を得ている ${ }^{84)}$.

この他, 信号の読出しに関するあのとして, 高真空に 封じた管でバイアス電流を得る方法が提案されている. これは, 焦電材料 $\mathrm{PVF}_{2}$ (polyvynilydene fluoride) タ ーゲットの走査側に微細なストライプ電極あるいは細か

\footnotetext{
* DTGS: deuterated triglycine sulphate の略称で, TGS の中の 一部の水素を重水素で置換し，キュリー温度を $\left(49^{\circ} \mathrm{C}\right.$ から $61^{\circ} \mathrm{C}$ に上げ，焦電係数む向上させた材料.
} 


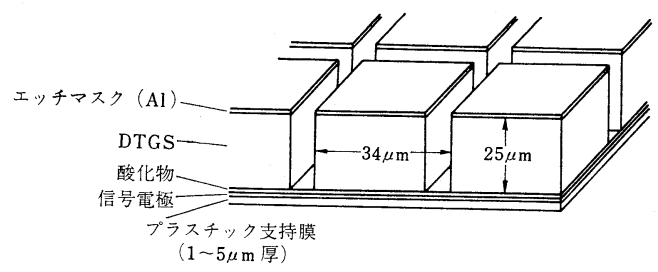

図 7 モザイク状ターゲットの部分拡大図

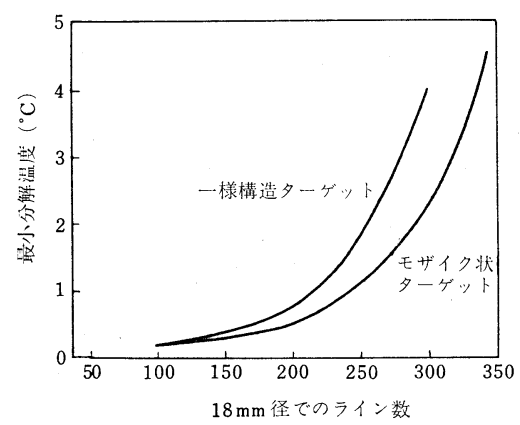

図 8 モザイク状ターゲットと一様構造ターゲットの 最小分解温度の比較

いモザイク電極を蒸着し，その上を啇度の抵抗值をむつ 高抵抗膜で覆ったものである ${ }^{85)}$.

この他, $\mathrm{PVF}_{2}$ 形でガス封入管を含め, 電子ビーム系 について検討した報告 ${ }^{86)}$ や焦電形ビジコンの出力画像を 見易くするための信号処理についての報告がある87).

$\mathrm{X}$ 線用ではその $\mathrm{PbO}$ ターゲット膜の構造之暗電流, 降伏電圧, 残像などとの関係が調べられた ${ }^{88)}$. 光導電形 の不可視光ビジコンとしては赤外線用, 紫外〜可視光 用，X線用が国内でも製品化されているが89)，乙の他， 特殊用途にイメージディセクターもつくられて招り, $\mathrm{MM}$ 形 $(26 \mathrm{~mm} \phi, 38 \mathrm{~mm} \phi, 75 \mathrm{~mm} \phi), \mathrm{SS}(38 \mathrm{~mm} \phi)$ 形がある ${ }^{89)}$.

\section{6. む び}

ここ 5 年位の動きの中から，とくに新しいところに重 点を置いてまとめた. この分野であ我が国は量質共にト ップレベルにあって活況を呈している. したがって，本 文の内容む国内のものが多く，海外の状況については調 查の行き届いていない面むあるかと思う．終りに本文作 成にあたり，最新情報を寄せられた多くの諸兄に深謝す る.

（昭和 56 年 5 月 11 日受付)

\section{〔参 考 文 献〕}

1）二宮：撮像管における新技術の展開，テレビ全大， S-5 (1980) 433

2) 小楠: ダイオードガン方式撮像管, テレビ誌, 34,8 (1980) $726-730$

3) 小特集 小形カラーカメラ, テレビ誌, 35, 3 (1981)
176-199

4) 形名 H9366 (2/3インチ), H9369 (1 インチ), 日立力 タログ (1980)

5) 形名 XQ 3427，松下電子 (1981)

6) 坂井 : 低出力容量化ビジコンと前置増幅器, テレビ誌, 29, 8 (1975) 648-652

7) 和久井 : サチコンと小形カラーカメラへの応用, NHK 技研月報, 19, 10 (1976) 378-384

8) I. Shimizu, S. Oda, K. Saito, H. Tomita, E. Inoue: Studies on Primary Photocurrent of a-Si : H Using Xerographic and Vidicon Technique, Conf. Tetrahed. Bond. Amorph. Semicond., Arizona (1981)

9) 今村, 阿高, 高崎, 草野, 石岡, 平井, 丸山: アモルフ アスシリコンを用いた撮像管，信学技報， ED 80-62 (1980)

10）野々部, 大久保, 原田, 梶山, 市川：フレアー防止ビジ コンの特性, テレビ全大, 2-9 (1977)

11）䐠木，永山：ダイオードガンプランビコン，テレビ技報, 3, 17, ED-461 (1979)

12）梶山，島，星山，門田：酸化鉛ターゲットビジコン“工 一ビコン” LD 6024，日電技報， 120 (1977) 104

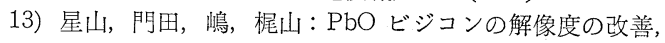
テレビ全大, 2-8 (1977)

14）遠藤, 山本, 岩沢, 吉田：カルニコンの信号保持特性, テレビ全大, 3-6 (1976)

15) 吉田, 林元, 長栄: カルニコンの立ち上がり残像の改善, テレビ全大，2-9 (1978)

16）真鍋, 吉田, 林元, 長栄：カルニコンターゲットの膜構 造の改造, テレビ全大, 2-7 (1977)

17) 真鍋, 吉野, 長栄, 林元, 吉田: 赤外増感カルニコンの 試作，テレビ全大，2-8 (1978)

18）宇田, 丸山, 坪井, 山田, 後藤: 非晶質カルコゲナイド 系撮像管の動作解析，テレビ全大，3-11 (1976)

19）飯田, 藤田, 市川: 単管撮像管における三硫化アンチモ ン膜とサチコン膜の比較, テレビ全大, 2-10 (1978)

20）藤原, 倉本, 近村, 深井: 高感度撮像管“ニュービコ ン”の暗電流, テレビ全大, 3-12 (1976)

21）藤原, 近村, 倉本, 深井: ニュービコン膜のブロッキン グ効果，テレビ全大，2-6 (1977)

22）板垣, 山本, 藤原: 近赤外増感型ニュービコン, テレビ 学会電子装置研資, ED-303 (1976)

23）倉本, 藤原, 柴田, 深井, 山本, 板垣 : ニュービコンの 青感度向上，テレビ学会技報， 1，6，ED-357 (1977)

24) 形名 S 4121 (1 インチ), S 4131 (2/3 インチ), 松下電 子 (1981)

25) 藤, 河野: シリコンビジコンの軟 $\mathrm{X}$ 線損傷とその防止, 信学技報, ED 75-84 (1976)

26）花岡：新型シリコンビジコンの低照度特性, 日電技報, 116 (1977) 64

27) 花岡, 高崎, 村山：シリコンビジコンのビームランディ ング特性，信学技報， ED 76-27 (1976)

28) 小楠: 電子ビーム径の限界とその要因, テレビ学会電子 装置研資, ED-316 (1977)

29）作左部, 井上, 木内：ビジコンの電子ビームスポットの 直接測定, テレビ学会電子装置研資, ED-238 (1975)

30) 木内, 作左部 : ビジコンの電子ビームの直接測定 II, テ レビ学会電子装置研資, ED-300 (1976)

31) 本多, 畑中, 安藤: NEA 冷陰極を用いた撮像管電子レ ンズの解析, テレビ全大, 3-3 (1980)

32) 岡崎, 奥出, 倉重, 小楠, 朝比奈: 精密微細加工, 組み 立て技術の撮像管への適用之その動向，テレビ学会技報， 4, 43, ED-561 (1981)

33）磯崎, 熊田, 奥出, 小楠, 後藤 : 高品位 $\mathrm{T} \mathrm{V}$ 用 1 インチ 
サチコン，テレビ学会技報，3，4，ED-447 (1979)

34) 永山：高解像度 ACT “プランビコン”, National Tech. Rep., 25, 2 (1979)

35）寺島, 梶原, 植野: $\mathrm{Ni}-\mathrm{Ba}-\mathrm{Mg}$ 基体合金によるカソー ドの特性, テレビ学会技報, 3，11，ED-452 (1979)

36) 柴田, 木村, 桜井: 含浸形カソードの概要之特性改良に ついて，テレビ学会技報，3，11，ED-453 (1979)

37）樋口，小林，設楽：バリウム含浸型陰極の排気特性とガ ス被毒特性，テレビ学会技報，3，11，ED-454 (1979)

38) H. Kan, T. Nakamura, H. Katsuno, M. Hagino, T. Sukegawa: New Structure GaP-GaAlP Heterojunction Cold Cathode, IEEE Trans., ED-26, 11 (1979) 1759-1766

39) H. Kan, T. Nakamura, H. Katsuno, M. Hagino, T. Sukegawa: New activation methods for longlife and highly stable GaP-GaAlP heterojunction cold cathodes, J. Appl. Phys., 51, 6 (1980) 34043408

40) Y. Hatanaka, T. Kawai, T. Sukegawa, T. Ando, R. Nishida: A Camera Tube with NEA Cold Cathode, IEEE Trans., ED-28, 1 (1981) 72-76

41) 境, 滝川, 岩崎: 短縮形撮像管による小形ハンディカメ ラ, テレビ全大，4-16 (1979)

42) 作左部, 木内：1インチビジコンの 2 ループ集束方式, テレビ学会技報，3，30，ED-466 (1979)

43) 昆, 作左部, 木内: 1 インチビジコンの 2 ループ CMF 集束方式，テレビ全大，3-5 (1980)

44) C. I. Coleman, W. A. Delamere, et al: Recent Developments in Permanent Magnet Focusing Asemblies for Image Intensifiers and Camera Tubes, Advances in Electronics and Electron Physics, 52 (1979) 89-99

45) 長原, 天野, 池村, 石橋, 渡辺, 渡辺: 家庭用カラーカ メラ，テレビ誌，35，3 (1981) 184

46) 丸山, 福島 : 静電集束 - 電磁偏向形撮像管の偏向収差解 析, 信学技報, ED 80-45 (1980)

47) K. Schlesinger, R. A. Wagner: A Mixed-Field Type Vidicon, IEEE Trans., ED-14, 3 (1967) 163-170

48）蠣崎, 難波, 田川, 沢井, 窪田: 電磁集束 ・静電偏向型 ビジコンの軌道解析, テレビ学会電子装置研資, ED-320 (1977)

49）窪田, 蠣崎: トリニコンカラーカメラ, テレビ学会技報, 2, 24, ED-422 (1979)

50) 倉重: 層流形電子銃のMS 形撮像管への適用, テレビ学 会技報, 4, 27, ED-536 (1980)

51) H. G. Lubszynski, et al : New all-electrostatic vidicon, Proc. IEE, 116, 3 (1969) 339-347

52) 西田, 加藤：新しい集束偏向系を用いた全静電型ビジコ ンの試作，静大電子工学研研報， 8，2 (1973) 47-52

53) 渡辺, 永井, 杉淵：ビジコン用静電型電子銃, 信学技報, ED 76-110 (1977)

54) 富井：撮像管における水平偏向直線性の垂直相関, テレ ビ全大, 3-1 (1978)

55）倉重：低速度ビームランディングにおけるセルフシャー プニング効果 (第 2 報), テレビ学会技報, 2, 15, ED398 (1978)

56) 倉重: 低速度ビームランディングにおけるセルフシャー プニング効果 (第 4 報)，テレビ学会技報， $3 ， 4, \mathrm{ED}-$ 446 (1979)

57) 倉重：低速度ビームランディングにおけるシャープニン グ効果 (第 5 報)，信学技報, ED 80-46 (1980)

58) 畑中, 青山, 安藤: 撮像管ビーム系と解像度および残像, 信学技報, ED 80-119 (1980)

\section{撮像管に関する最近の研究と開発の動向 $\square$ 技術解説}

59) W. V. McCollough: A Model for Signal Generation in Silicon Target Camera Tube, Advances in Electronics and Electron Physics, 52 (1979) 63-73

60) L.D. Miller: A New Method of Specifying the Resolving Power of Television Camera Tubes Using the RCA P-300 Test Chart, SMPTE J., 89 (1980) 249-256

61) R. G. Neuhauser: Measuring Camera-Tube Resolution with the RCA P 200 Test Chart, RCA 資料 (1979)

62）倉重：撮像管電子ビーム系と容量性残像之の因果関係, NHK 技術研究，30，2 (1978) 45-57

63) 谷岡: フィードバック法による撮像管の残像改善効果, 第 29 回 NHK 四国管内技報会予 (1976) 28-29

64) 倉重：フィードバック法による撮像管容量性残像改善の 電子ビーム光学的検討, テレビ学会技報, $1,6, \mathrm{ED}-351$ (1977)

65）高木, 清水, 山下 : マイクロコンピュータを導入した撮 像管用残像測定器の開発, テレビ学会技報, $3,4, \mathrm{ED}-$ 448 (1979)

66) 首藤, 小堀, 児玉, 増田, 高橋, 宮地：可変波長光パル ス光源による残像測定の検討, テレビ全大, 3-1 (1980)

67) 竹才: 高速度ビーム走查による光導電形撮像管, テレビ 学会技報, 2，3，ED-388 (1978)

68) 藤原, 田中, 矢野, 青木, 児玉, 関口: 新構造ストライ プフィルターを用いた単管カラー撮像管, テレビ学会技 報, 4, 43, ED-562 (1981)

69) 電波新聞（昭56.2.12）

70) 笹野, 中野, 松丸, 筒井, 西村, 長原: 3 電極方式単管 カラーカメラ用ビジコン, テレビ誌， 29,6 (1975) 485490

71) 長原, 天野, 池村, 石橋, 渡辺, 渡辺: 家庭用力ラーカ メラ, テレビ誌, 35, 3 (1981) 190-192

72) 高橋, 長原 : 3 電極管のメッシュ電極加らの信号検出, テレビ全大, 3-2 (1978)

73) Y. Kubota, T. Kakizaki: An ENG Colour Camera Using Single Pick-up Tube, International Broadcating Convention Report (1980)

74) Y. Isozaki: The 2-In Return-Beam Saticon, SMPTE J., 87, 8 (1978) 489-493

75) 河村: 近接集束形 SEC ビジコン, NHK 技術研究, 32, 2 (1980) 45-73

76) T. Kawamura, S. Okude, S. Okazaki, H. Washida, K. Yano: Proximity Focused SEC Vidicon with Porous $\mathrm{MgF}_{2}-\mathrm{Ag}$ Target, Advances in Electronics and Electron Physics, 52 (1979) 51-61

77) 柳沢，河村：近接形イメージインテンシファイヤの開発 とその応用，テレビ学会技報，3，44，ED-488 (1980)

78) 形名 E 5801，E 5801(B)，東芝カタログ (1980)

79) 山本：ファイバープレート付“ニュービコン”, National Tech. Report, 25, 2 (1979) 298-308

80) 形名 C 21205, RCA カタログ (1979)

81) 形名 F 4546, ITT カタログ (1979)

82) 鈴木, 木下, 中山, 金田, 丹羽: 真空紫外線用撮像蓄積 管,テレビ誌, 33，2 (1979) 114-119

83) 木下, 加藤, 鈴木: 紫外線用イメージ管, テレビ全大, 3-8 (1980)

84) P. J. Pool, D. J. Pedder: A Pyroelectric Vidcon with Recticulated Target, Advances in Electronics and Electron Physics, 52 (1979) 23-30

85) 岡本, 畑中, 安藤, 西田: 高真空動作用焦電型ターゲッ トの構造, テレビ全大, 2-2 (1978)

86) 岡本, 畑中, 青山, 安藤: $\mathrm{PVF}_{2}$ 焦電ビジコンにおりる 電子ビーム系の検討, テレビ全大, 3-2 (1980)

87) 寺西, 大庭, 高橋, 山香: 焦電ビジコンの信号処理, テ レビ学会技報，4，27，ED-535 (1980)

88) 河合, 中山, 内山, 野上: X線ビジコンターゲットの蒸 着結晶膜, 電気関係学会東海支部連大予 (1980) 427

89) 浜松テレビカタログ

90) 形名 BC 4398 B, G, R, RCA 資料 (1981) 